\title{
Glutamine: A Major Gluconeogenic Precursor and Vehicle for Interorgan Carbon Transport in Man
}

\author{
N. Nurjhan, ${ }^{\star}$ A. Bucci, ${ }^{\ddagger}$ G. Perriello, ${ }^{\star}$ M. Stumvoll, ${ }^{\star \S}$ G. Dailey, $\$$ D. M. Bier, $"$ I. Toft, " T. G. Jenssen, " and J. E. Gerich ${ }^{\star \S}$ \\ $*$ The University of Rochester School of Medicine, Rochester, New York 14642; ${ }^{\ddagger}$ University of Pittsburgh, Department of Medicine, \\ Pittsburgh, Pennsylvania 15261; ${ }^{\S}$ Division of Endocrinology and Metabolism, Scripps Clinic, La Jolla, California 92037; "Washington \\ University School of Medicine, Metabolism Division,St. Louis, Missouri 63110; and "University Hospital of Tromso, Department of \\ Medicine, Tromso, Norway
}

\begin{abstract}
To compare glutamine and alanine as gluconeogenic precursors, we simultaneously measured their systemic turnovers, clearances, and incorporation into plasma glucose, their skeletal muscle uptake and release, and the proportion of their appearance in plasma directly due to their release from protein in postabsorptive normal volunteers. We infused the volunteers with $\left[\mathrm{U}-{ }^{14} \mathrm{C}\right]$ glutamine, $\left[3-{ }^{13} \mathrm{C}\right]$ alanine, $\left[{ }^{2} \mathrm{H}_{5}\right]$ phenylalanine, and $\left[6^{-3} \mathrm{H}\right]$ glucose to isotopic steady state and used the forearm balance technique. We found that glutamine appearance in plasma exceeded that of alanine (5.76 \pm 0.26 vs. $\left.4.40 \pm 0.33 \mu \mathrm{mol} \cdot \mathrm{kg}^{-1} \cdot \mathrm{min}^{-1}, P<0.001\right)$, while alanine clearance exceeded glutamine clearance $\left(14.7 \pm 1.3\right.$ vs. $\left.9.3 \pm 0.8 \mathrm{ml} \cdot \mathrm{kg}^{-1} \cdot \mathrm{min}^{-1}, P<0.001\right)$. Glutamine appearance in plasma directly due to its release from protein was more than double that of alanine $(2.45 \pm 0.25 \mathrm{vs}$. $\left.1.16 \pm 0.12 \mu \mathrm{mol} \cdot \mathrm{kg}^{-1} \cdot \mathrm{min}^{-1}, P<0.001\right)$. Although overall carbon transfer to glucose from glutamine and alanine was comparable $\left(3.53 \pm 0.24\right.$ vs $3.47 \pm 0.32$ atoms $\left.\cdot \mathrm{kg}^{-1} \cdot \mathrm{min}^{-1}\right)$, nearly twice as much glucose carbon came from protein derived glutamine than alanine $(1.48 \pm 0.15$ vs $0.88 \pm 0.09$ atoms $\left.\cdot \mathrm{kg}^{-1} \cdot \mathrm{min}^{-1}, P<0.01\right)$. Finally, forearm muscle released more glutamine than alanine $(0.88 \pm 0.05$ vs $0.48 \pm 0.05$ $\left.\mu \mathrm{mol} \cdot 100 \mathrm{ml}^{-1} \cdot \mathrm{min}^{-1}, P<0.01\right)$. We conclude that in postabsorptive humans glutamine is quantitatively more important than alanine for transporting protein-derived carbon through plasma and adding these carbons to the glucose pool. (J. Clin. Invest. 1995. 95:272-277.) Key words: glutamine $\bullet$ alanine $\bullet$ gluconeogenesis $\bullet$ muscle $\bullet$ liver
\end{abstract}

\section{Introduction}

Lactate, glycerol, and certain amino acids account for nearly all of the carbon that is transported through the circulation and incorporated into plasma glucose by the liver and kidney (1, 2 ). However, more plasma glucose is converted to plasma lactate than comes from plasma lactate (3-5), and glycerol be-

Address correspondence to John E. Gerich, M.D., University of Rochester, 601 Elmwood Ave., Box MED/CRC, Rochester, NY 14642. D. M. Bier's present address is Children's Nutrition Research Center, Baylor College of Medicine, Houston, TX 77030.

Received for publication 28 March 1994 and in revised form $6 \mathrm{July}$ 1994.

J. Clin. Invest.

(C) The American Society for Clinical Investigation, Inc.

0021-9738/95/01/0272/06 \$2.00

Volume 95, January 1995, 272-277 comes a quantitatively important gluconeogenic precursor only when there is accelerated lipolysis such as after prolonged fasting (6), and in diabetes mellitus (7). Consequently, under normal circumstances, amino acids are largely responsible for the net addition of carbons to the glucose pool which are not immediately derived from plasma glucose.

At the present time, alanine is widely believed to be the most important gluconeogenic amino acid $(8-11)$. This view is mainly based on splanchnic and limb balance studies (1219), which provided evidence that both the release of alanine from muscle and its uptake by splanchnic tissues exceeded those of all other amino acids. However, this concept must be readdressed on several grounds: first, isotopic studies of the incorporation of labeled alanine into plasma glucose indicate that it accounts for only $\sim 5 \%$ of glucose appearing in plasma $(5$, 20-23). Second, since a substantial proportion of alanine, like lactate, comes directly from glucose (24-27), conversion of alanine to glucose may result in little net addition of carbon to the glucose pool. Third, most of the above early balance studies (12-16) had not evaluated glutamine, the most abundant amino acid in human plasma (28-30) and muscle (31). Finally, alanine unlike glutamine is not apparently incorporated into glucose by the kidney $(2,32-34)$ which recent studies suggest may be a more important producer of glucose than previously believed $(35,36)$

Both in vitro studies and experiments in animals have shown glutamine to be one of the most efficient substrates for gluconeogenesis $(37-40)$. It is the major gluconeogenic precursor in the kidney $(2,32)$. Furthermore in contrast to alanine, the carbon skeleton of glutamine appears to originate mainly from protein and other amino acids $(26,41)$. Consequently, conversion of glutamine to glucose might provide more new carbon to the glucose pool than alanine.

Based on some of the foregoing considerations and their own balance data, Marliss et al. (19) had originally suggested that glutamine may be an important gluconeogenic precursor in humans. However, Felig et al. (18) were unable to substantiate this hypothesis, at least with respect to hepatic gluconeogenesis, since their measurements of arterial, hepatic venous, and portal venous glutamine concentrations suggested that most, if not all, splanchnic glutamine uptake was due to nonhepatic splanchnic tissues. It is, of course, possible that the glutamine taken up by nonhepatic splanchnic tissues might be converted to other precursors (e.g., alanine, lactate, or glutamate) which subsequently became incorporated into glucose in the liver. To date conversion of glutamine carbon to glucose carbon has not been directly examined in humans. With the use of an isotopic tracer, it is possible to assess incorporation of glutamine carbon into glucose and other substrates. Furthermore, with judicious combination of isotopic tracers, one can assess simultaneously the 
Table I. Clinical Metabolic Characteristics of Subjects

\begin{tabular}{lc}
\hline Gender & 4 men, 7 women \\
Age $(\mathrm{yr})$ & $49 \pm 2$ \\
Body Mass Index $\left(\mathrm{kg} / \mathrm{m}^{2}\right)$ & $23.1 \pm 0.7$ \\
Body Weight $(\mathrm{kg})$ & $68.8 \pm 3.3$ \\
Muscle Mass $(\mathrm{kg})$ & $23.7 \pm 1.3$ \\
Forearm Blood Flow $\left(\mathrm{ml} \cdot 100 \mathrm{ml}^{-1} \cdot \mathrm{min}^{-1}\right)$ & $3.30 \pm 0.18$
\end{tabular}

appearance of alanine and glutamine in plasma glucose and estimate the relative fractions of their appearance arising directly from their release from protein.

Therefore to assess the relative importance of alanine and glutamine as gluconeogenic precursors providing additional carbon to the glucose pool not immediately derived from plasma glucose, we simultaneously compared the incorporation of [U${ }^{14} \mathrm{C}$ ] glutamine and $\left[3-{ }^{13} \mathrm{C}\right.$ ] alanine carbon into plasma glucose, the systemic turnovers and clearances of these amino acids, their uptake and release from skeletal muscle, and the proportion of their appearance in plasma due to their direct release from protein in 11 overnight fasted healthy volunteers. Our results indicate that in postabsorptive humans $(a)$ rates of glutamine appearance in plasma and release from muscle from greater than those of alanine; $(b)$ of their appearance in plasma and incorporation into glucose, more glutamine than alanine is derived directly from its release from protein and thus $(c)$ glutamine appears to be quantitatively more important than alanine in terms of transporting protein-derived carbon through plasma and adding these to the glucose pool.

\section{Methods}

Subjects. Informed written consent was obtained from 11 normal volunteers after the protocol has been approved by local Institutional Review Boards. All subjects (whose clinical characteristics are given in Table I) had normal glucose tolerance tests and no family history of diabetes. They had been on a weight maintaining diet containing at least $200 \mathrm{gm}$ carbohydrate and had abstained from alcohol for at least $3 \mathrm{~d}$ before study.

Protocol. Subjects were admitted to the General Clinical Research Unit either at the University of Pittsburgh (Pittsburgh, PA) or at Scripps Clinic (La Jolla, CA) between 4 and 6 p.m. in the evening before experiments, they consumed a standard meal $(10 \mathrm{Kcal} / \mathrm{kg}, 50 \%$ carbohydrate, $35 \%$ fat, and $15 \%$ protein) between 6 and 8 p.m. and were fasted overnight until experiments were completed.

At approximately 4 a.m., an antecubital vein was cannulated and primed-continuous infusions of $\left[6^{-3} \mathrm{H}\right]$ glucose $(20 \mu \mathrm{Ci}, 0.2 \mu \mathrm{Ci} / \mathrm{min})$, [ $\mathrm{U}-{ }^{14} \mathrm{C}$ ] glutamine $(20 \mu \mathrm{Ci}, 0.2 \mu \mathrm{Ci} / \mathrm{min}),\left[3-{ }^{13} \mathrm{C}\right]$ alanine $\left(99 \%{ }^{13} \mathrm{C}\right.$, $2 \mathrm{mmol}, 20 \mu \mathrm{mol} / \mathrm{min}),\left[{ }^{2}-\mathrm{H}_{5}\right]$ phenylalanine $\left(99 \%{ }^{2} \mathrm{H}, 2 \mu \mathrm{mol} / \mathrm{kg}\right.$, $0.03 \mu \mathrm{mol} \cdot \mathrm{kg}^{-1} \cdot \mathrm{min}^{-1}$ ) were begun. At the same time, a bolus of 50 $\mu \mathrm{Ci}$ of $\left[{ }^{14} \mathrm{C}\right]$ sodium bicarbonate was also administered to prime the endogenous bicarbonate pool. At 7:00 a.m. the ipsilateral radial artery $(n=5)$ or dorsal hand vein $(n=6)$ and a contralateral deep antecubital vein were cannulated for blood sampling. When the dorsal hand vein was used to obtain arterialized-venous blood, the hand was maintained in a thermoregulated Plexiglas box at $65^{\circ} \mathrm{C}$. Several previous studies have found no difference between simultaneously sampled arterial and arterialized-venous glutamine and alanine concentrations $(28,29)$. After these findings were confirmed in the initial studies, arterialized venous sampling was used in place of arterial sampling and for simplicity all data are referred to as arterialized.

After allowing $\sim 4 \mathrm{~h}$ to achieve isotopic steady state, four blood samples were collected simultaneously from the radial artery (or dorsal hand vein) and the deep antecubital vein at 20-min intervals over the next hour for determination of plasma substrate concentrations, specific activities and stable isotope enrichments. During this interval, total $\mathrm{CO}_{2}$ production was measured twice using a metabolic measurement cart (Sensormedics, Anaheim, CA). Before and after these measurements, breath samples were collected by directing expiratory air through a $0.5 \mathrm{M}$ hyamine hydroxide in methanol solution (VWR, Cerritos, CA). Forearm blood flow was determined immediately before the first and after the last blood sampling using electrocapacitance plethysmography as previously described (5).

Analytical procedures. All blood samples were placed immediately in a $4^{\circ} \mathrm{C}$ ice bath and plasma was separated within $30 \mathrm{~min}$ by centrifugation at $4^{\circ} \mathrm{C}$. For subsequent measurement of glutamine, glutamate, and alanine concentrations, an internal standard $(25 \mathrm{nmol}$ of $p$-fluoro-dlphenylalanine) was added to $3 \mathrm{ml}$ of plasma. The plasma was deproteinized with $3 \mathrm{ml}$ of ice-cold perchloric acid ( $7 \% \mathrm{wt} / \mathrm{vol}$ ). After centrifugation the supernatant was processed according to the method of Smith and Panico (30) by adding $0.6 \mathrm{ml}$ of $4 \mathrm{mM}$ sodium acetate buffer $\mathrm{pH}$ 4.8 and adjusting the $\mathrm{pH}$ between 4.8 and 5.0 with $5 \mathrm{~N}$ potassium hydroxide. After centrifugation the supernatants were frozen at $-20^{\circ} \mathrm{C}$ until the time of analysis.

Plasma glucose was determined with a glucose analyzer (Yellow Springs Instrument Co., Yellow Springs, $\mathrm{OH}$ ). Plasma glutamine, glutamate and alanine concentrations and the specific activities of glutamine and alanine were determined by high performance liquid chromatography using a modification (42) of the method of Smith and Panico (30). Plasma $\left[{ }^{3} \mathrm{H}\right]$ and $\left[{ }^{14} \mathrm{C}\right]$ glucose specific activities were determined using ion exchange chromatography as previously described $(5)$. Plasma $\left[{ }^{13} \mathrm{C}\right]$ glucose and alanine enrichment and plasma $\left[{ }^{2} \mathrm{H}\right]$ phenylalanine enrichment were measured by chemical ionization and selected ion monitoring gas chromatography-mass spectrometry of penta-acetate (glucose) and $\mathrm{N}$-acetyl-n-propyl ester derivatives (alanine and phenylalanine), as previously described $(5,43)$.

Calculations. At steady state, the rate of appearance $\left(R_{\mathrm{a}}\right)$ of a substrate in plasma equals its rate of disappearance $\left(R_{\mathrm{d}}\right)$ from plasma (44). Plasma glucose and glutamine $\mathrm{R}_{\mathrm{a}}$ and $R_{\mathrm{d}}$ were obtained by dividing the $\left[6-{ }^{3} \mathrm{H}\right]$ glucose and $\left[{ }^{14} \mathrm{C}\right]$ glutamine infusion rates $\left(\mathrm{dpm} \cdot \mathrm{kg}^{-1} \cdot \mathrm{min}^{-1}\right)$ by the arterialized plasma $\left[6-{ }^{3} \mathrm{H}\right]$ glucose and $\left[{ }^{14} \mathrm{C}\right]$ glutamine specific activities (sp act; dpm/ $\mu \mathrm{mol}$ ) (44), respectively. Plasma alanine and phenylalanine $R_{\mathrm{a}}$ and $R_{\mathrm{d}}$ were obtained according to the following equation (44): $R_{\mathrm{a}}=I\left(E_{\mathrm{i}} / E_{\mathrm{p}}-1\right)$ where $I$ is the tracer infusion rate $\left(\mu \mathrm{mol} \cdot \mathrm{kg}^{-1} \cdot \mathrm{min}^{-1}\right), E_{\mathrm{i}}$ is the enrichment of the infused tracer (mole percent excess), and $E_{\mathrm{p}}$ is the arterialized isotopic enrichment of plasma tracer (mole percent excess).

The systemic clearance of glutamine and alanine (MCR) were calculated by dividing their $R_{\mathrm{d}}$ by their arterialized plasma concentration.

The percent of plasma glucose and alanine derived from plasma glutamine and the percent of plasma glucose derived from plasma alanine were calculated respectively as:

$\frac{\left[{ }^{14} \mathrm{C}\right] \text { alanine sp act } \times 100 \times 5}{\left[{ }^{14} \mathrm{C}\right] \text { glutamine sp act } \times 3}$,

$\frac{\left[{ }^{14} \mathrm{C}\right] \text { glucose sp act } \times 100 \times 5}{\left[{ }^{14} \mathrm{C}\right] \text { glutamine sp act } \times 6}$, and

$\left[{ }^{13} \mathrm{C}\right]$ glucose enrichment $\times 100$

$\left[{ }^{13} \mathrm{C}\right]$ plasma alanine enrichment $\times 2$.

The rates at which carbons of plasma glucose were derived from carbons of glutamine and alanine were calculated as the product of the rate of appearance in plasma of glucose, the percent of their derivation from the precursor and the number of carbons in glucose. It is appreciated that the amounts of glucose derived from alanine and glutamine represent minimal estimates because of carbon exchange in the Krebs cycle (45). This underestimation, which in humans has been reported to be between 15 and $40 \%(5,46)$, should be greater with use of [U$\left.{ }^{14} \mathrm{C}\right]$ glutamine as a tracer than with use of $\left[3-{ }^{13} \mathrm{C}\right]$ alanine as a tracer 
$(45,47)$ and thus the relative contribution of glutamine is underestimated to a greater extent than that of alanine.

The rate at which plasma glucose carbon was derived from plasma alanine carbon was corrected for the alanine derived from glutamine by multiplying the uncorrected rate of glucose carbon appearance in plasma derived from alanine by ( 100 - the percent of alanine derived from glutamine).

The rate of appearance in plasma of glutamine and alanine due to their release from protein was calculated as described by Darmaun et al. (43). This approach is based on the concept that since phenylalanine is an essential amino acid which cannot be synthesized in vivo, its only source in the postabsorptive state is its release from protein. Thus, release of glutamine and alanine directly from protein can be estimated using the rate of phenylalanine appearance in plasma and the relative contents of phenylalanine, glutamine and alanine in body protein with the equation $R a_{\mathrm{p}}\left(k_{\mathrm{NE}} / k_{\mathrm{p}}\right)$, where $R a_{\mathrm{p}}$ is the phenylalanine appearance rate: $k_{\mathrm{NE}}$ is the concentration of either alanine or glutamine in body protein and $k_{\mathrm{p}}$ is the concentration of phenylalanine in body protein. Values of 4.3, 6.6, and $13.9 \mathrm{~g}$ amino acid $/ 100 \mathrm{~g}$ protein were used for the concentrations of phenylalanine, alanine and glutamine respectively, based on averages of amino acid composition of mammalian tissues, as previously described (43)

Plasma glutamine oxidation $\left(\mu \mathrm{mol} \cdot \mathrm{kg}^{-1} \cdot \mathrm{min}^{-1}\right)$, as represented by the incorporation of ${ }^{14} \mathrm{C}$ into breath $\mathrm{CO}_{2}$, was calculated as:

$\underline{\left[{ }^{14} \mathrm{CO}_{2}\right] \mathrm{sp} \text { act } \times \mathrm{CO}_{2} \text { production } \times 5}$

$\left[{ }^{14} \mathrm{C}\right]$ glutamine sp act $\times 0.81$

where $\mathrm{CO}_{2}$ production is in $\mu \mathrm{mol} \cdot \mathrm{kg}^{-1} \cdot \mathrm{min}^{-1}$ and 0.81 is used to correct for incomplete recovery of $\mathrm{CO}_{2}$ in breath.

Net forearm balance of glutamine and alanine was calculated by multiplying arteriovenous (AV) differences in substrate concentrations by forearm blood flow. Forearm fractional extraction of $\left[{ }^{14} \mathrm{C}\right]$ glutamine was calculated as the arteriovenous difference in $\left[{ }^{14} \mathrm{C}\right]$ glutamine concentration divided by the arterialized $\left[{ }^{14} \mathrm{C}\right]$ glutamine concentration. Forearm alanine fractional extraction was calculated in an analogous manner using $\left[{ }^{13} \mathrm{C}\right]$ alanine concentrations. Forearm substrate uptake was calculated as the product of the arterial concentration, blood flow, and fractional extraction (5). Forearm substrate release was calculated according to the equation: release $=$ uptake - net balance (5).

Data per 100-ml forearm tissue were converted to data per $\mathrm{kg}$ forearm muscle as previously described (5) by multiplying the data by 13.3 , assuming that muscle tissue has a density of 1.0 , that it represents $\sim 60 \%$ of the forearm volume, and that $80 \%$ of the blood flow to the forearm is directed to the muscle tissue. Total body muscle mass $(\mathrm{kg})$ was calculated using anthropomorphic measurements (height, mid-arm circumference and triceps skinfolds) according to the equations by Heymsfield et al. (48). Forearm muscle data were extrapolated to total body muscle by multiplying forearm muscle data by total body muscle mass.

Data are given as means \pm SE. Alanine and glutamine data were compared using the Wicoxon non-parametric test for paired samples (49). A $P$ value of $<0.05$ was considered statistically significant.

\section{Results}

Plasma arterialized substrate concentrations, specific activities and enrichments, and breath ${ }^{14} \mathrm{CO}_{2}$ specific activities (Table II) were stable during the sampling period indicating that an isotopic steady state had been achieved. The arterialized glutamine concentration (648 $\pm 34 \mu \mathrm{mol} /$ liter) was approximately twofold greater than that of alanine $(325 \pm 33 \mu \mathrm{mol} / \mathrm{liter}, P<0.001)$ and more than 10 -fold greater than that of glutamate $(52 \pm 5$ $\mu \mathrm{mol} /$ liter $)$. The difference in circulating glutamine and alanine concentrations was a consequence (Table III), of both a greater rate of glutamine appearance $(5.76 \pm 0.26$ vs. $4.40 \pm 0.33 \mu \mathrm{mol}$. $\mathrm{kg}^{-1} \cdot \mathrm{min}^{-1}$ for alanine, $\left.P<0.01\right)$ and a lower rate of glutamine clearance from plasma $\left(9.3 \pm 0.8\right.$ vs. $14.7 \pm 1.3 \mathrm{ml} \cdot \mathrm{kg}^{-1} \cdot \mathrm{min}^{-1}$ for alanine, $P<0.001$ ).

The rate of appearance in plasma of phenylalanine was $0.76 \pm 0.08 \mu \mathrm{mol} \cdot \mathrm{kg}^{-1} \cdot \mathrm{min}^{-1}$. Since this is an essential amino acid and is not synthesized in humans, its appearance in plasma reflects its release from protein. Using the rate of release of phenylalanine into plasma and the relative contents of phenylalanine, glutamine and alanine in body protein (42), it was calculated that twice as much glutamine as alanine entered plasma as a result of direct release of the amino acids from protein $\left(2.45 \pm 0.25\right.$ vs $\left.1.16 \pm 0.12 \mu \mathrm{mol} \cdot \mathrm{kg}^{-1} \cdot \mathrm{min}^{-1}, P<0.001\right)$. Moreover, this accounted for a greater proportion of the overall appearance of glutamine than alanine $(42 \pm 4$ vs. $27 \pm 3 \%, P$ $<0.001)$. Approximately $6 \%$ of alanine entering plasma $\left(0.27 \pm 0.03 \mu \mathrm{mol} \cdot \mathrm{kg}^{-1} \cdot \mathrm{min}^{-1}\right)$ was derived from glutamine.

The overall rate of glucose appearance in plasma averaged $12.1 \pm 0.5 \mu \mathrm{mol} \cdot \mathrm{kg}^{-1} \cdot \mathrm{min}^{-1}$. Approximately $5 \%$ of the glucose carbon was derived from glutamine carbon $(3.53 \pm 0.24$ atoms. $\left.\mathrm{kg}^{-1} \cdot \mathrm{min}^{-1}\right)$ and $5 \%$ from alanine carbon $(3.47 \pm 0.32$ atoms. $\left.\mathrm{kg}^{-1} \cdot \min ^{-1}\right)$. However, nearly twice as much of the glucose carbon derived from glutamine carbon came directly from release of the amino acid from protein $(0.25 \pm 0.03$ vs. $0.15 \pm 0.01$ $\mu \mathrm{mol} \cdot \mathrm{kg}^{-1} \cdot \mathrm{min}^{-1}$ for alanine, $\left.P<0.001\right)$.

There was net release of both glutamine and alanine by forearm tissues and net uptake of glutamate (Table IV). Fractional extraction of glutamine $(26 \pm 2 \%)$ and alanine $(30 \pm 3 \%)$ across forearm tissues were comparable (Table IV). Nevertheless, forearm tissues took up more glutamine $(0.57 \pm 0.07 \mathrm{vs}$. $0.31 \pm 0.04 \mu \mathrm{mol} \cdot \mathrm{kg}^{-1} \cdot \mathrm{min}^{-1}$ for alanine, $\left.P<0.05\right)$ and also released more glutamine $\left(0.88 \pm 0.05\right.$ vs. $0.48 \pm 0.05 \mu \mathrm{mol} \cdot \mathrm{kg}^{-1}$. $\min ^{-1}$ for alanine, $\left.P<0.05\right)$.

Extrapolation of these data to total body muscle (Table III) indicated that release of glutamine from muscle $(274 \pm 16$ $\mu \mathrm{mol} \cdot \mathrm{min}^{-1}$ ) accounted for $71 \pm 4 \%$ of its appearance in plasma, and muscle uptake $\left(178 \pm 22 \mu \mathrm{mol} \cdot \mathrm{min}^{-1}\right)$ accounted for $46 \pm 5 \%$ of its removal from plasma. Approximately $40 \%$ of the glutamine removed from plasma was oxidized $(2.56 \pm 0.50$ $\left.\mu \mathrm{mol} \cdot \mathrm{kg}^{-1} \cdot \mathrm{min}^{-1}\right)$. Release of alanine from muscle $(142 \pm 21$ $\mu \mathrm{mol} \cdot \mathrm{min}^{-1}$ ) accounted for $47 \pm 5 \%$ of its appearance in plasma, and muscle uptake $\left(92 \pm 20 \mu \mathrm{mol} \cdot \mathrm{min}^{-1}\right)$ accounted for $31 \pm 4 \%$ of its removal.

\section{Discussion}

Previous studies of glutamine metabolism in humans have used either the net balance technique (which does not permit individual assessment of glutamine uptake and release) or the infusion of ${ }^{15} \mathrm{~N}$-labeled glutamine which traces the flux of the nitrogens of glutamine and not necessarily its carbon skeleton and does not permit assessment of the gluconeogenic potential of glutamine. The recent development of a simple and precise HPLC method to measure $\left[{ }^{14} \mathrm{C}\right]$ glutamine (and alanine) specific activity in plasma (42) made it feasible for us to delineate certain key features of glutamine carbon metabolism and compare them with those of alanine.

Alanine is widely considered to be the major gluconeogenic amino acid. However, our results indicate that comparable amounts of glucose are produced from glutamine and alanine. Moreover we found that muscle released more glutamine and that more of the glutamine carbon released into plasma and transferred to glucose came from protein. Our results thus suggest that glutamine is a more important vehicle than alanine for 
Table II. Substrate Concentrations, Specific Activities, and Enrichments in Arterialized Plasma or Breath (Mean士SEM)

\begin{tabular}{|c|c|c|c|c|c|}
\hline & \multicolumn{5}{|c|}{ Minutes after starting isotope infusions } \\
\hline & 240 & 260 & 280 & 300 & Mean \\
\hline \multicolumn{6}{|c|}{ Concentration ( $\mu \mathrm{mol} /$ liter $)$} \\
\hline Glucose & $5150 \pm 73$ & $5148 \pm 77$ & $5187 \pm 86$ & $5124 \pm 81$ & $5152 \pm 78$ \\
\hline Glutamine & $647 \pm 37$ & $683 \pm 30$ & $643 \pm 37$ & $619 \pm 36$ & $48 \pm 34$ \\
\hline Alanine & $342 \pm 33$ & $323 \pm 28$ & $322 \pm 30$ & $311 \pm 29$ & $325 \pm 33$ \\
\hline Glutamate & $54 \pm 3$ & $50 \pm 5$ & $54 \pm 6$ & $50 \pm 5$ & $52 \pm 5$ \\
\hline \multicolumn{6}{|c|}{$\left[{ }^{14} \mathrm{C}\right]$ Specific activity $(\mathrm{dpm} / \mu \mathrm{mol})$} \\
\hline Glucose & $63 \pm 3$ & $61 \pm 3$ & $65 \pm 3$ & $65 \pm 3$ & $64 \pm 3$ \\
\hline Glutamine & $1092 \pm 69$ & $1121 \pm 82$ & $1122 \pm 81$ & $1138 \pm 80$ & $1118 \pm 77$ \\
\hline Alanine & $36 \pm 4$ & $38 \pm 5$ & $49 \pm 8$ & $38 \pm 6$ & $40 \pm 5$ \\
\hline $\mathrm{CO}_{2}$ & - & $17 \pm 2$ & - & $17 \pm 2$ & $17 \pm 2$ \\
\hline \multicolumn{6}{|c|}{$\left[{ }^{3} \mathrm{H}\right]$ Specific activity $(\mathrm{dpm} / \mu \mathrm{mol})$} \\
\hline Glucose & $346 \pm 24$ & $330 \pm 23$ & $336 \pm 25$ & $338 \pm 25$ & $337 \pm 24$ \\
\hline \multicolumn{6}{|c|}{$\left[{ }^{13} \mathrm{C}\right]$ Enrichment (mole percentage excess) } \\
\hline Glucose & $0.63 \pm 0.08$ & $0.63 \pm 0.07$ & $0.65 \pm 0.07$ & $0.67 \pm 0.07$ & $0.66 \pm 0.06$ \\
\hline Alanine & $6.46 \pm 0.50$ & $6.60 \pm 0.61$ & $6.21 \pm 0.55$ & $6.57 \pm 0.57$ & $6.46 \pm 0.46$ \\
\hline \multicolumn{6}{|c|}{$\left.{ }^{2} \mathrm{H}\right]$ Enrichment (mole percentage excess) } \\
\hline Phenylalanine & $6.15 \pm 1.01$ & $6.13 \pm 1.03$ & $6.01 \pm 1.03$ & $6.27 \pm 1.13$ & $6.14 \pm 0.87$ \\
\hline
\end{tabular}

transporting protein-derived carbon through plasma and expanding the plasma glucose pool with carbon not immediately derived from glucose.

Plasma glutamine concentrations generally exceed those of alanine by $2-4$-fold $(28-30)$. Our results confirm this and provide an explanation since we found that the rate of glutamine appearance in plasma was greater than that of alanine, whereas clearance of alanine was greater than that of glutamine.

The rate of glutamine appearance in plasma measured with $\left[\mathrm{U}-{ }^{14} \mathrm{C}\right.$ ] glutamine as tracer was $\sim 20 \%$ greater than those re-

Table III. Systemic Glutamine and Alanine Metabolism

\begin{tabular}{|c|c|c|c|}
\hline & Glutamine & Alanine & $P$ \\
\hline Overall $\mathbf{R}_{\mathrm{a}}\left(\mu \mathrm{mol} \cdot \mathrm{kg}^{-1} \cdot \mathrm{min}^{-1}\right)$ & $5.76 \pm 0.26$ & $4.40 \pm 0.33$ & $<0.001$ \\
\hline $\operatorname{MCR}\left(\mathrm{ml} \cdot \mathrm{kg}^{-1} \cdot \mathrm{min}^{-1}\right)$ & $9.3 \pm 0.8$ & $14.7 \pm 1.3$ & $<0.001$ \\
\hline \multicolumn{4}{|l|}{ Release directly from protein } \\
\hline$\left(\mu \mathrm{mol} \cdot \mathrm{kg}^{-1} \cdot \min ^{-1}\right)$ & $2.45 \pm 0.25$ & $1.16 \pm 0.12$ & $<0.001$ \\
\hline Percentage of Overall $R_{a}$ & $42 \pm 4$ & $27 \pm 3$ & $<0.001$ \\
\hline \multicolumn{4}{|l|}{ Glucose carbon from } \\
\hline$\left(\right.$ atoms $\left.\cdot \mathrm{kg}^{-1} \cdot \min ^{-1}\right)$ & $3.59 \pm 0.24$ & $3.47 \pm 0.32$ & NS \\
\hline $\begin{array}{l}\text { Percentage of Overall } \mathbf{R}_{\mathbf{a}} \\
\text { Oxidation }\end{array}$ & $12 \pm 1$ & $27 \pm 3$ & $<0.001$ \\
\hline$\left(\mu \mathrm{mol} \cdot \mathrm{kg}^{-1} \cdot \mathrm{min}^{-1}\right)$ & $2.56 \pm 0.50$ & - & - \\
\hline Percentage of Overall $R_{d}$ & $42 \pm 6$ & - & - \\
\hline \multicolumn{4}{|l|}{$\mathbf{R}_{\mathbf{a}}$ From Glutamine } \\
\hline$\left(\mu \mathrm{mol} \cdot \mathrm{kg}^{-1} \cdot \min ^{-1}\right)$ & - & $0.27 \pm 0.03$ & - \\
\hline Percentage of Overall $\mathbf{R}_{\mathbf{a}}$ & - & $6 \pm 1$ & - \\
\hline \multicolumn{4}{|l|}{ Uptake by Muscle } \\
\hline$\left(\mu \mathrm{mol} \cdot \mathrm{kg}^{-1} \cdot \min ^{-1}\right)$ & $178 \pm 22$ & $92 \pm 20$ & $<0.01$ \\
\hline Percentage of Overall $R_{d}$ & $46 \pm 5$ & $31 \pm 4$ & $<0.01$ \\
\hline \multicolumn{4}{|l|}{ Release by Muscle } \\
\hline$\left(\mu \mathrm{mol} \cdot \mathrm{kg}^{-1} \cdot \min ^{-1}\right)$ & $274 \pm 16$ & $142 \pm 21$ & $<0.01$ \\
\hline Percentage of Overall $R_{a}$ & $71 \pm 4$ & $47 \pm 5$ & $<0.05$ \\
\hline
\end{tabular}

ported using $\left[2-{ }^{15} \mathrm{~N}\right]$ glutamine in normal volunteers $(43,50-$ 53 ). Whether this truly represents differences in glutamine nitrogen and carbon fluxes will require simultaneous measurements with carbon and nitrogen labeled glutamine. Nevertheless Darmaun et al. (43) using $\left[2-{ }^{15} \mathrm{~N}\right]$ glutamine and $\left[{ }^{13} \mathrm{C}\right]$ alanine as tracers also found that rate of appearance of glutamine in plasma was greater than that of alanine.

In terms of transporting carbon through plasma from protein to tissues which can incorporate this carbon into other substrates, our results indicate that glutamine plays a major, if not dominant role. Consistent with previous reports using a combination of $\left[{ }^{15} \mathrm{~N}\right]$ glutamine and $\left[{ }^{2} \mathrm{H}_{5}\right]$ phenylalanine infusions $(52,53)$, we found that approximately $40 \%$ of glutamine appearance in plasma was due to direct release of the amino acid from protein. This was $1 \frac{1 / 2}{2}$ times greater than the proportion of alanine directly derived from protein. Since the overall rate of appearance of glutamine in plasma was also greater than that of alanine, the amount of glutamine carbon derived directly from protein that entered plasma was more than twofold greater than that of alanine.

Table IV. Forearm Glutamine, Alanine, and Glutamate Metabolism

\begin{tabular}{lcccc}
\hline & Glutamine & Alanine & Glutamate & $P^{*}$ \\
\hline $\begin{array}{l}\text { (A-V) difference } \\
\quad(\mu \text { mol/liter })\end{array}$ & $-102 \pm 17$ & $-52 \pm 6$ & $18 \pm 2$ & $<0.01$ \\
$\begin{array}{l}\text { Fractional Extraction }(\%) \\
\text { Net Balance } \\
\quad\left(\mu \mathrm{mol} \cdot 100 \mathrm{ml} \cdot \mathrm{min}^{-1}\right)\end{array}$ & $-0.31 \pm 0.04$ & $-0.17 \pm 0.02$ & $0.06 \pm 0.01$ & $<0.01$ \\
$\begin{array}{l}\text { Uptake } \\
\left(\mu \mathrm{mol} \cdot 100 \mathrm{ml} \cdot \mathrm{min}^{-1}\right)\end{array}$ & $0.57 \pm 0.07$ & $0.31 \pm 0.04$ & - & $<0.01$ \\
$\begin{array}{l}\text { Release } \\
\left(\mu \mathrm{mol} \cdot 100 \mathrm{ml} \cdot \mathrm{min}^{-1}\right)\end{array}$ & $0.88 \pm 0.05$ & $0.48 \pm 0.05$ & - & $<0.01$ \\
\hline
\end{tabular}

* Glutamine vs. alanine. 
It should be noted that the above calculation represents minimal estimates of the amount of protein carbon transferred through plasma as glutamine and alanine since it reflects only the carbon transferred as a consequence of the content of glutamine and alanine in protein. Additional protein-derived carbon could be transferred through plasma as glutamine and alanine due to their formation from other amino acids released from protein $(53,54)$. For alanine, this appears to be minimal $(25$, 55 ); but for glutamine, this could be quite substantial. Although glutamine accounts for only $10-15 \%$ of the amino acids in muscle protein, it represents more than $30 \%$ of the amino acids released from muscle $(17,23)$. Consequently a considerable portion of the glutamine released from muscle is probably due to its synthesis from other protein-derived amino acids whose release is less than expected from their content in muscle protein (53). There is at the present time no evidence to suggest that an appreciable glucose-glutamine cycle exists analogous to the glucose-alanine cycle (55). Therefore based on these considerations, it would appear that glutamine is a more important vehicle than alanine for transport through plasma of protein-derived carbon.

Of further interest is our observation that $\sim 6 \%$ of alanine originated from glutamine. It had been proposed based on animal and in vitro studies that a substantial amount of glutamine is taken up by the gastrointestinal tract and converted to alanine (56-58). If all of the alanine originating from glutamine in the present study had been produced in the gastrointestinal tract, our results indicate that in postabsorptive humans generation of alanine from glutamine is neither a major source of alanine nor a major metabolic pathway for glutamine. Consistent with these observations are the results of Dechelotte et al. (59) who infused glutamine into the jejunum of normal volunteers at a rate equal to its systemic turnover and found a nonsignificant increase in de novo alanine synthesis, which represented $\sim 2 \%$ of the infused glutamine. This is similar to the proportion of glutamine $R_{\mathrm{d}}$ $(2.9 \pm 0.3 \%)$ found in the present study to be accounted for by conversion to alanine.

Our forearm balance results confirm some earlier observations that more glutamine than alanine is released from human limbs $(17,23,60-65)$. Extrapolation of our forearm data to total body muscle indicated that muscle release of glutamine and alanine accounted for $\sim 70$ and $50 \%$ respectively of their total rate of appearance in the circulation and that muscle uptake accounted for $\sim 45 \%$ of glutamine and $30 \%$ of alanine removal from plasma. Matthews et al. (51) found a fractional extraction of $55 \%$ for glutamine across the splanchnic bed in normal volunteers infused intragastrically with $\left[2-{ }^{15} \mathrm{~N}\right]$ glutamine. Taken together our results and those of Matthews et al. (53) suggest that muscle and the splanchnic bed (liver plus gastrointestinal tissues) are the predominant sites of glutamine removal from the systemic circulation in postabsorptive humans. However, it should be pointed out that fractional extraction of glutamine across the human kidney has not been reported, and the kidney may be another important site of glutamine removal from plasma $(2,32)$ and conversion to glucose $(35,36)$.

Transfer of protein carbon via glutamine and alanine to glucose is accompanied by transfer of nitrogen through plasma and the need for its disposal as glucose is formed from these amino acids. In the case of glutamine, twice as much nitrogen would have to be disposed of compared to alanine. This would be expected to occur mainly through ureagenesis in the liver and through ammoniagenesis in the kidney, both of which are coupled to gluconeogenesis $(5,32,66,67)$. Another mechanism might involve transamination of branched chain keto acids to their amino acids. It has been estimated that in humans branched chain amino acids could provide as much as $60 \%$ of the nitrogen used for de novo synthesis of alanine (68); a similar situation may hold for glutamine although this has not been examined. The liver possesses the ability to transaminate branched chain keto acids (69). It is possible therefore that some of the nitrogen resulting from glutamine and alanine conversion to glucose in the liver may be disposed of by concomitant formation of branched chain amino acids from their keto acids which could then transfer nitrogen back to muscle to make it available for glutamine and alanine synthesis. Such a process would provide a mechanism for nitrogen sparing during accelerated or prolonged gluconeogenesis.

In summary, the present studies indicate that in postabsorptive humans $(a)$ the rate of appearance of glutamine in plasma is greater than that of alanine; $(b)$ muscle release of glutamine exceeds that of alanine; and $(c)$ since more glutamine carbon than alanine released into plasma and incorporated into plasma glucose is derived directly from proteolysis, glutamine appears to be quantitatively more important than alanine as a vehicle for transporting protein carbon through plasma and as a gluconeogenic precursor in terms of adding these new carbons to the plasma glucose pool.

\section{Acknowledgments}

We thank the staff of the General Clinical Research Center and the research volunteers; Jorunn Eikrem, Hege Iversen, Nina Vassvik, Dawn Purdy, Carol Korbanic, Dan Kirsch, Doris McMillen, and Howard Christopherson for their excellent technical help; and Laura Brinker and Sandy Webster for their expert editorial assistance.

This work was supported in part by the Institut National de la Sante et de la Recherche Medicale (INSERM), the Fogarty International Foundation, the Norwegian Council of Science, the Norwegian Association of Diabetes, Nordisk Insulinfond, the Norwegian Odd Fellow Research Funding, NIDDK/DK-20411, 20579, and HD-20805, the University of Pittsburgh Research Training in Diabetes and Endocrinology 5T32DK07052-19 and the NIH/DRR/GCRC grants No. 5M01 RR 00056,000954 , and 00044.

\section{References}

1. Exton, J. 1972. Gluconeogenesis. Metabolism. 21:945-990.

2. Wirthensohn, G., and Guder, W. 1986. Renal substrate metabolism. Physiol. Rev. 66:469-497.

3. Kreisberg, R. A., L. F. Pennington, and B. R. Boshell. 1970. Lactate turnover and gluconeogenesis in normal and obese humans. Diabetes. 19:53-63.

4. Katz, H., M. Homan, M., P. Butler, and R. Rizza. 1992. Use of [3-3H]glucose and [6-14C] glucose to measure glucose turnover and glucose metabolism in humans. Am. J. Physiol. 26:E17-E22.

5. Consoli, A., N. Nurjhan, D. Bier, J. Reilly, and J. Gerich. 1990. Contribution of liver and skeletal muscle to alanine and lactate metabolism in man. Am. J. Physiol. 259:E677-E685.

6. Bortz, W. M., P. Paul, A. C. Haff, and W. L. Holmes. 1972. Glycerol turnover and oxidation in man. J. Clin. Invest. 51:1537-1546.

7. Nurjhan, N., A. Consoli, and J. Gerich. 1992. Increased lipolysis and its consequences on gluconeogenesis in noninsulin-dependent diabetes mellitus. $J$. Clin. Invest. 89:169-175.

8. Olefsky, J. 1985. Diabetes mellitus, In Cecil Textbook of Medicine. J. Wyngaarden and L. Smith, editors W. B. Saunders, Philadelphia, PA. 1334.

9. Rodwell, V. 1985. Catabolism of amino acid nitrogen. In Harper's Review of Biochemistry. Martin, D., P. Mayes, V. Rodwell, and D. Granner. Lang Medical Publications, Los Altos, CA. 288.

10. Newsholme, E., and A. Leech. 1986. Carbohydrate metabolism in the liver. In Biochemistry for the Medical Sciences. John Wiley and Sons, New York. 442-480. 
11. Felig, P., and Berman, M. 1990. Integrated physiology of carbohydrate metabolism. In Diabetes Mellitus Theory and Practice. H. Rifkin, and D. Porte, editors. Ellenberg and Ribkins, New York. 52.

12. Felig, P., O. Owen, J. Wahren, and G. Cahill. 1969. Amino acid metabolism during prolonged starvation. J. Clin. Invest. 48:584-594.

13. Pozefsky, T., P. Felig, J. Tobin, J. Soeldner, and G. Cahill. 1969. Amino acid balance across tissues of the forearm in postabsorptive man: effects of insulin at two-dose levels. J. Clin. Invest. 48:2273-2282.

14. Felig, P., T. Pozefsky, E. Marliss, and G. Cahill. 1970. Alanine: key role in gluconeogenesis. Science (Wash. DC). 167:1003-1004.

15. Felig, P., and J. Wahren. 1971. Amino acid metabolism in exercising man J. Clin. Invest. 50:2703-2714.

16. Felig, P., J. Wahren, and R. Lars. 1973. Evidence for interorgan amino acid transport by blood red cells in humans. Proc. Natl. Acad. Sci. USA. 70:17751779.

17. Wahren, J., P. Felig, and L. Hagenfeldt. 1976. Effect of protein ingestion on splanchnic and leg metabolism in normal man and in patients with diabetes mellitus. J. Clin. Invest. 57:987-999.

18. Felig, P., J. Wahren, I. Karl, E. Cerasi, R. Luft, and D. Kipnis. 1973 Glutamine and glutamine metabolism in normal and diabetic subjects. Diabetes. 22:573-576.

19. Marliss, E., T. Aoki, T. Pozefsky, A. Most, and G. Cahill. 1971. Muscle and splanchnic glutamine and glutamate metabolism in postabsorptive and starved man. J. Clin. Invest. 50:814-817.

20. Chiasson, J., J. Liljenquist, B. Sinclair-Smith, and W. Lacy. 1975. Gluconeogenesis from alanine in normal postabsorptive man: intrahepatic stimulatory effect of glucagon. Diabetes. 24:574-584.

21. Bier, D., K. Arnold, W. Sherman, W. Holland, W. Holmes, and D. Kipnis. 1977. In vivo measurement of glucose and alanine metabolism with stable isotopes. Diabetes. 26:1005-1015.

22. Hall, S., J. Braaten, J. McKendry, T. Bolton, D. Foster, and M. Berman. 1979. Normal alanine-glucose relationships and their changes in diabetic patients before and after insulin treatment. Diabetes. 28:737-745.

23. Sandler, M., R. Robinson, D. Rabin, W. Lacy, and N. Abumrad. 1983. The effects of thyroid hormones on gluconeogenesis and forearm metabolism in man. J. Clin. Endo. \& Metab. 56:479-485.

24. Odessey, R., E. Khairallah, and A. Goldberg. 1974. Origin and possible significance of alanine production by skeletal muscle. J. Biol. Chem. 249:76237627.

25. Chang, T., and A. Goldberg. 1978. The origin of alanine produced in skeletal muscle. J. Biol. Chem. 253:3677-3684.

26. Goldberg, A., and T. Chang. 1978. Regulation and significance of amino acid metabolism in skeletal muscle. Fed. Proc. 37:2301-2307.

27. Waterhouse, C., and J. Keilson. 1978. The contribution of glucose to alanine metabolism in man. J. Lab. Clin. Med. 92:803-812.

28. Abumrad, N., D. Rabin, M. Diamond, and W. Lacy. 1981. Use of a heated superficial hand vein as an alternative site for the measurement of amino acid concentrations and for the study of glucose and alanine kinetics in man. Metabolism. 30:936-940.

29. Brooks, D., M. Black, T. Arcangeli, T. Aoki, and D. Wilmore. 1989. The heated dorsal hand vein: an alternative arterial sampling site. J.P.E.N. 13:102105.

30. Smith, R., and K. Panico. 1985. Automated analyses of O-phthalaldehyde derivatives of amino acids in physiological fluids by reverse phase high performance liquid chromatography. J. Liq. Chromat. 8:1783-1795.

31. Bergstrom, J., P. Fiirst, L.-O. Noree, and E. Vinnars. 1974. Intracellular free amino acid concentration in human muscle tissue. J. Appl. Physiol. 36:693697.

32. Schoolwerth, A., B. Smith, and R. Culpepper. 1994. Renal gluconeogenesis. Min. Electr. Metab. 14:347-361.

33. Castellano, P., and R. A. DeFronzo. 1990. Glucose metabolism and the kidney. Semin. Nephrol. 10:458-463.

34. Bjorkman, O., P. Felig, and J. Wahren. 1980. The contrasting responses of splanchnic and renal glucose output to gluconeogenic substrates and to hypoglucagonemia in 60h fasted humans. Diabetes. 29:610-616.

35. Cersosimo, E., R. Judd, and J. Miles. 1994. Insulin regulation of renal glucose metabolism in conscious dogs. Am. J. Physiol. 93:2584-2589.

36. McGuinness, O., T. Fugiwara, S. Muyrell, D. Bracy, D. Neal, D. O'Connor, and A. Cherrington. 1993. Impact of chronic stress hormone infusion on hepatic carbohydrate metabolism in the conscious dog. Am. J. Physiol. 265:E314E322.

37. Ross, B. D., R. Hems, R. A. Freeland, and H. A. Krebs. 1967. Carbohydrate metabolism of the perfused rat liver. Biochem. J. 105(2):869-875.

38. Brockman, R., and E. Bergman. 1975. Effect of glucagon on plasma alanine and glutamine metabolism and hepatic gluconeogenesis in sheep. Am. J. Physiol. 228:1627-1633.
39. Bergman, E., and R. Heitmann. 1978. Metabolism of amino acids by the gut, liver, kidneys, and peripheral tissues. Fed. Proc. 37:1228-1232.

40. Kaloyianni, M., and R. A. Freedland. 1990. Contribution of several amino acids and lactate to gluconeogenesis in hepatocytes isolated from rats fed various diets. J. Nutr. 120:116-122.

41. Garber, A., I. Karl, and D. Kipnis. 1976. Alanine and glutamine synthesis and release from skeletal muscle II the precursor role of amino acids in alanine and glutamine synthesis. J. Biol. Chem. 251:836-843.

42. Jenssen, T., N. Nurjhan, G. Perriello, A. Bucci, I. Toft, and J. Gerich. 1994. Determination of [14C] glutamine specific activity in plasma. J. Liq. Chromat. 17:1337-1348.

43. Darmaun, D., D. E. Matthews, and D. M. Bier. 1988. Physiological hypercorisolemia increases proteolysis, glutamine, and alanine production. Am. J. Physiol. 255:E366-E373.

44. Wolfe, R. 1992. Radioactive and stable isotope tracers in biomedicine: principles and practice of kinetic analysis. Wiley-Liss, New York

45. Katz, J. 1985. Determination of gluconeogenesis in vivo with [14C]labelled substrates. Am. J. Physiol. 248:R331-R339.

46. Magnusson, I., W. Schumann, G. Bartsch, V. Chandramouli, K. Kumaran, J. Wahren, and B. Landau. 1991. Noninvasive tracing of Krebs cycle metabolism in liver. J. Biochem. 266:6975-6984.

47. Vinay, P., J. Mapes, and H. Krebs. 1978. Fate of glutamine carbon in renal metabolism. Am. J. Physiol. 234:F123-F129.

48. Heymsfield, S., C. McManus, V. Stevens, and J. Smith. 1982. Muscle mass: reliable indicator of protein-energy malnutrition seventy and outcome. $\mathbf{A m}$. J. Clin. Nutr. 35:1192-1199.

49. Zar, J. 1984. Biostatistical analysis. Prentice Hall, Englewoods Cliffs, NJ. 50. Matthews, D., G. Pesola, and R. Campbell. 1990. Effect of epinephrine on amino acid and energy metabolism in humans. Am. J. Physiol. 258:E948E956.

51. Matthews, D., M. Marano, and R. Campbell. 1993. Splanchnic bed utilization of glutamine and glutamic acid in humans. Am. J. Physiol. 264:E848-E854.

52. Matthews, D., and G. Campbell. 1992. The effect of dietary protein intake on glutamine and glutamate nitrogen metabolism in humans. Am. J. Clin. Nutr. 55:963-970

53. Darmaun, D., D. Matthews, and D. Bier. 1986. Glutamine and glutamate kinetics in humans. Am. J. Physiol. 251:E117-E126.

54. Chang, T., and A. Goldberg. 1978. The metabolic fates of amino acids and the formation of glutamine in skeletal muscle. J. Biol. Chem. 253:36853695 .

55. Felig, P. 1975. Amino acid metabolism in man. Ann. Rev. Biochem. 44:933-955

56. Windmueller, H. 1982. Glutamine utilization by the small intestine. Adv. Enzymol. Reg. 53:202-237.

57. Souba, W. 1987. Interorgan ammonia metabolism in health and disease: A surgeon's view. J.P.E.N. 11:569-579.

58. Ardawi, M., Y. Jamal, A. Ashy, H. Nasr, and E. Newsholme. 1990 Glucose and glutamine metabolism in the small intestine of septic rats. J. Lab. Clin. Med. 115:660-668.

59. Dechelotte, P., D. Darmaun, M. Rongier, B. Hecketsweiler, O. Rigal, and J. F. Desjeux. 1991. Absorption and metabolic effects of enterally administered glutamine in humans. Am. J. Physiol. 260:G677-G682.

60. Wicklmayr, M., K. Rett, B. Schwiegelsholn, G. Wolfram, S. Hailer, and G. Dietze. 1987. Inhibition of muscular amino acid release by lipid infusion in man. Eur. J. Clin. Invest. 17:301-305.

61. Elia, M., P. Folmer, A. Schlatmann, A. Goren, and S. Austin. 1989. Amino acid metabolism in muscle and in whole body of man before and after ingestion of a single mixed meal. Am. J. Clin. Nutr. 49:1203-1210.

62. Pozefsky, T., R. Tancredi, R. Moxley, J. Dupre, and J. Tobin. 1976. Effects of brief starvation on muscle amino acid metabolism in nonobese man. J. Clin. Invest. 57:444-449.

63. Abumrad, N., D. Rabin, K. Wise, and W. Lacy. 1982. The disposal of an intravenously administered amino acid load across the human forearm. Metabolism. 31:463-470.

64. Morrison, W., J. Gibson, R. Jung, and M. Rennie. 1988. Skeletal muscle and whole body protein turnover in thyroid disease. Eur. J. Clin. Invest. 18:6268.

65. Lochs, H. E. Roth, S. Gasic, W. Hubl, E. Morse, and S. A. Adibi. 1990 Splanchnic, renal and muscle clearance of alanylglutamine in man and organ fluxes of alanine and glutamine when infused in free dual peptide forms. Metabolism. 39:833-836.

66. Meijer, A., C. Lof, I. Ramos, and A. Verhoven. 1985. Control of ureagenesis. Eur. J. Biochem. 148:189-196.

67. Tannen, R. 1978. Ammonia metabolism. Am. J. Physiol. 235:F265-F277.

68. Haymond, M. W., and J. Miles. 1989. Branched-chain amino acids as a major source of alanine nitrogen in man. Diabetes. 31:86-89.

69. Walser, M., P. Lund, N. Ruderman, and A. Coulter. 1973. Synthesis of essential amino acids from their alpha-keto analogues by perfused rat liver and muscle. J. Clin. Invest. 52:2865-2877. 